\title{
Assessment of Sustainable Development of the Residential Construction Sector in the Context of Sustainable City Development in Poland
}

\author{
Marcin Sitek ${ }^{1}$
}

\begin{abstract}
The issue of quality of life in large agglomerations has become more and more important for many years. The challenges faced by the real estate market relate to its planned further development taking into account all dimensions of sustainable development. The aim of the work is to assess the state of sustainable development of the residential construction sector in Poland. The work assumes that sustainable development of construction is one of the factors determining sustainable development of cities. The research was based on statistical data describing housing resource in Poland and on analyses and reports published by the Central Statistical Office, NBP, Responsible Business Forum and Agenda for Sustainable Development 2030. The goals of Agenda 2030 were discussed with particular emphasis on stability and sustainability of the real estate market. The value of the urbanization index for large agglomerations in Poland confirmed the very positive effects of the sustainable development of the real estate market. The paper attempts to determine the relationship between the economic value of the housing sector and the consumption of environmental resources, which may lead to the establishment of an indicator that is a new tool for assessing sustainable development. The analysis carried out in the work thus confirmed the legitimacy of the thesis put in place, leading to the realization of the aim of the work
\end{abstract}

Keywords: Agenda 2030, urbanization, construction sector, real estate market, sustainable development

\section{Introduction}

The concept of sustainable building dates back to the period of oil crisis in the 1970 s in the USA and the increasing concerns about pollution to the natural environment. In that period, the need arose for building more energy-efficient structures and introduction of environmentally-friendly construction processes.

The construction sector in the European Union accounts for $10 \%$ GDP (Bunikowska,2010; Gorzeń-Mitka et al., 2016), employing 7\% of the EU's workforce. European buildings consume $42 \%$ energy and produce $35 \%$ greenhouse gases in the entire EU. Over 50\% of materials extracted from the earth (after processing) is used in the construction sector. Therefore, energy savings, the use of renewable energy sources and limitation of gas emissions should be started from this sector. Sustainable building, focused on the preservation of the environment, caring for health and well-being of building users, became one of the priority sectors in the EU. The European Commission included sustainable building into lead market initiative i.e. those with very high innovative potential and key importance to the development of modern economy in Europe.

For this policy, the framework for the EU was provided mainly by the Treaty of Lisbon,

$\mid{ }^{1}$ Częstochowa University of Technology, Faculty of Management, Department of Economics, Investments and Real Estate, Poland 
which implemented the territorial dimension as equal to the economic and social dimension and helped take into consideration the territorial dimension in individual policies of the EU, with particular focus on cohesion policy. Territorial aspects and urban division were also emphasized in the Europe 2020 strategy. In Poland, the framework for the regional and spatial policies is provided by: National Regional Development Strategy for 2010-2020: Regions, cities, urban area and Concept of Spatial Development in the Country 2030.

Polish regional policy has been implemented for several years in the regionally-oriented manner, allowing for the performance of activities that face the challenges of sustainable development while adjusting to local conditions.

\subsection{Sustainable Building}

Sustainable building, also termed green building, combines a number of practices and techniques that reduce and eliminate the negative effect of new buildings on natural environment and human health. The main aim of the project of the sustainable life cycle of the building is to minimize the negative impact of investments on the environment at each stage, from raising the structure through to its demolition (Sitek, 2016). One of the most popular techniques at the stage of construction is to use permeable concrete instead of the conventional one or asphalt in order to supplement resources of ground waters. Among the techniques that reduce and eliminate the negative impact of investments on the environment are those which concern the efficient use of energy, water, use of green construction materials, and limitation of volatile organic compounds in the building interior or waste minimization. The necessity has been emphasized to use renewable energy sources at the stage of the use of the building (passive solar, active solar technologies), photovoltaic technologies, the use of trees and plants to form green roofs, rain gardens, also in order to prevent the outflow of rain water.

Reduction of energy consumption in buildings and limitation of pollution which they form represent the basis for sustainable development. The construction sector consumes from 30 to $40 \%$ of energy (total consumption). Over $80 \%$ emissions of substances produced by building which are harmful to the environments are related to energy consumption (Bunikowska, 2010). It was demonstrated that implementation of the ecological solutions allows for saving $60-80 \%$ of energy.

The costs related to construction of green buildings are by ca. $5 \%$ higher than traditional building methods (Buro Happold, 2014). However, this investment is returned within 5 to 15 years. Green buildings help save from 30 to $50 \%$ energy, consume ca. $30 \%$ less water, and the $\mathrm{CO}_{2}$ emissions to the atmosphere are limited by nearly $40 \%$. Eventually, these buildings produce $70 \%$ less waste compared to standard buildings. Initial investment of $2-10 \%$ in the design can help save ca. $20 \%$ of total costs of the use during the life cycle of the building (Rodriguez et al., 2018).

Energy efficiency of the building and sustainable management of water resources is measured using the methodology of the evaluation of buildings form the standpoint of ecology. The most important and the most popular are the American system LEED (Leadership in Energy and Environmental Design) and the British system BREEAM (BRE Environmental Assessment Method). 
The effect of each technique and method of measurement of sustainable building offers not only measurable savings but it is also the priority for dynamic development of sustainable building and expresses the care especially for the natural environment and human health.

\subsection{National Urban Policy}

Since 2000, Poland has seen rapid urbanization and urban expansion since $65 \%$ of the country's population lives now in urban and intermediate areas (CSRinfo, 2017). In 2015, Poland has adopted the National Urban Policy in order to strengthen the ability of cities to reach sustainable development and create new job vacancies (Ministerstwo...,2014). However, a key challenge is, as emphasized by the Polish Strategy for responsible development, to ensure reasonable prices of flats. Despite a significant progress in limitation of the official deficit of flats due to the national programmes and initiatives at the stage of gminas, the percentage of overcrowded housing and low quality of residential buildings continues to be high. A relatively high percentage of the population is exposed to air pollution in the metropolitan areas (16.4\% in 2013, OECD mean: 11.0\%). Metropolitan areas in Poland show levels greater than the mean for OECD countries in terms of availability of green areas $\left(577 \mathrm{~m}^{2} /\right.$ million residents in 2013 compared to the OECD mean of $500 \mathrm{~m} 2$ ).

Since cities in Poland have to ensure best housing conditions and cleaner air, the recommendations were published (OECD, 2017) concerning the housing policy, reasonable prices and quality, ensuring financial benefits connected with the development of housing and limitation of air pollution and carbon dioxide in cities.

Therefore, one should emphasize that the problems of sustainable development in cities are becoming more and more important due to the growing number of people who migrate to urbanized areas. According to the UN reports, $60 \%$ of global population will have lived in cities by 2030 (Global..,2016-2017). In Poland (2016), this threshold has already been achieved (CSRinfo, 2017). For this reason, it is critical to manage cities in a sustainable manner, i.e. so that the place becomes friendly to its residents while respecting the rights of the generations to come to realize their needs in a way the today's generations live in terms of e.g. access to clean water and clean air.

It is business that mainly inspires partnership for sustainable cities and urban areas. Cooperation between inhabitants, administration of various levels and entrepreneurs is needed to ensure sustainable urbanization for all, real social cooperation, adequate quality of building, transportation, air quality and efficient waste management (Ostrowiecki, 2015).

The aim of the study is to assess the state of sustainable development of the residential construction sector in Poland from the standpoint of development of cities in Poland. It was postulated that business inspires partnership for sustainable cities and urban areas.

\section{Methodology}

Available related literature and results of empirical studies performed by Polish and foreign research centres were used to achieve the study aim. The study was based on statistical data concerning housing resources in Poland and analyses and reports 
published by the Central Statistical Office of Poland, NBP, Responsible Business Forum and Agenda for Sustainable Development 2030. Secondary information was used in the study concerning sustainable development of cities in Poland.

The adopted methodology allowed for presentation of the evaluation of sustainable development of the construction sectors in the context of the development of cities in Poland and confirmation of the presented thesis that the main initiator of the partnership cooperation for sustainable cities and urban areas is business.

\section{Assessment of Sustainable Development in the Construction Sector from the Standpoint of Urban Development}

Considering the enormous damage to the environment caused by the construction sector in Europe (especially in the developing cities) (Buro Happold, 2014) ${ }^{1}$, its development should be aimed at sustainability. For this reason, the European Commission, in the report "Roadmap to a Resource Efficient Europe", pointed to the construction sector as one of three sectors on which further activities for the effective use of the resource utilization have to be focused. The document which related to sustainable development of cities is the Leipzig Charter (OECD, 2017). It contains several provisions oriented at the development of cities towards sustainable and integrated activities that involve a broad range of entities for improved coordination, efficiency and synergy of activities. Planning of further development should take into consideration all dimensions of sustainable development: economic well-being, social balance and healthy living conditions.

In 2016, over half of global population (54.5\%) lived in cities (CSRinfo, 2017). It is estimated that in 2050, this number will have risen to $75 \%$. According to the UN's report, 23\% (1.7 billion people) lived in 2016 in cities with population of at least 1 million people. There are 31 cities all over the world with population of over 10 million people, and 45 cities with population of 5 to 10 million. The range of 1 to 5 million contains 436 cities, whereas the range of 0.5 to 1 million - 551 cities. Prognoses indicate that in 2030, at least 41 will reach the population of at least 10 million. Therefore, the problems of the quality of life are becoming more and more significant.

Therefore, due to intensifying urbanization, cities have to play more and more important role and more attention will be paid to sustainable development. Consequently, business is perceived as the main inspirer of partnership cooperation for sustainable cities and rural areas which, having knowledge, experience and financial resources can inspire various activities for sustainable cities (Forum.., 2014), since co-financing of sustainable solutions proposed by enterprises is a social and economic necessity.

The key document adopted by leaders of UN member states on 25 September 2015, 2030 Agenda for Sustainable Development (OECD,2017), defined ambitious plan used for transformation in five domains with key importance for humankind: people, planet, prosperity, peace and partnership. It includes 17 goals of sustainable development, which

\footnotetext{
1 Statistics of the European Commission as cited in Buro Happold (2014), Analysis of sustainable building in Poland. Survey of market perception. Construction Marketing Group, World Green Building Council, p. 10, http://www.unep.or.jp/ietc/focus/EnergyCities1.asp.
} 
were presented as "integrated and indivisible, global in nature and universally applicable". Similar to other OECD countries, Poland has searched for the method to implement the Agenda as effectively as possible and to achieve the goals of sustainable development, create job vacancies and improve quality of life of inhabitants.

\subsection{Status of the Polish Economy on the Eve of the Achievement of the Goals of the 2030 Agenda}

In the beginning of 2017, Poland implemented the Strategy for Responsible Development (Global..,2016-2017) . It concerned in particular the Goal 11, which is: "Make cities and human settlements inclusive, safe, resilient and sustainable". The achievement of the Goal 11 requires extensive activities. It assumes, by 2030, ensure access for all to affordable housing, means of transportation, increased urbanization, reduction in unfavourable indices of city's effect on the environment and access to green areas. It also assumes, by 2040, to increase the number of cities and human settlements that adopt and implement plans for effective use of natural resources and protection of cultural heritage and global heritage, support relations between rural and urban areas and support the countries which are the least developed in construction of sustainable buildings using local construction materials.

Polish economy has been developing the fastest since 2015. The prospects are also good for the development of the country (S\&P, 2018), since global economy, and particularly important eurozone, is characterized by a stable macroeconomic policy. Gross domestic product in the countries of eurozone in 2017 increased by $2.5 \%$, whereas Polish economy grew by $5.1 \%$. According to Nielsen, Consumer Confidence Index in Poland for the third quarter 2017 was 104 compared to 87 in Europe (The Conference .., 2017). This was caused by low employment, higher salaries and the Family 500+ support programme.

The expected levels of basic macroeconomic indices (2015-2018) with prognostic data (2018-2020) as a picture of a resilient economic policy of Poland are presented in Table 1.

Table 1. Expected levels of basic macroeconomic indices in 2020

\begin{tabular}{|c|c|c|c|c|c|c|}
\hline Category & 2015 & 2016 & 2017 & 2018 & 2019 & 2020 \\
\hline Real GDP [\%] & 3.9 & 2.8 & 3.6 & 3.8 & 3.9 & 3.9 \\
\hline Private consumption ${ }^{2}[\%]$ & 3.2 & 3.6 & 4.1 & 3.8 & 3.6 & 3.5 \\
\hline Public consumption ${ }^{3}[\%]$ & 2.3 & 3.8 & 3.2 & 3.0 & 2.6 & 2.9 \\
\hline Gross fixed capital formation $[\%]$ & 6.1 & -5.5 & 5.9 & 6.6 & 6.6 & 6.8 \\
\hline GDP expressed in current prices (billion PLN) & 1798.3 & 1855.3 & 1954.2 & 2068.1 & 2197.3 & 2341.1 \\
\hline Consumer price index (CPI) [\%] & -0.9 & -0.5 & 1.3 & 1.8 & 2.2 & 2.5 \\
\hline Employed (BAEL) (15 years and more) [\%] & 1.4 & 0.9 & 0.5 & 0.4 & 0.4 & 0.3 \\
\hline Unemployment rate (BAEL) [\%] & 7.5 & 6.1 & 5.7 & 5.0 & 4.5 & 4.0 \\
\hline Gini coefficient $[\%]$ & 30.6 & 30.4 & 30.6 & - & - & $\begin{array}{l}30.5(2020) \\
27.0(2030)\end{array}$ \\
\hline
\end{tabular}

Source: Data as in (2015-q2 2018) - GUS, Prognostic data: the Budget Act 2018 MF

As results from the data presented in Table 1, the real increase in GDP in the nearest

2 Private consumption is individual consumption in the sector of households and consumption in the sector of non-commercial institutions

3 Public consumption: consumption concerning services provided for people and general social consumption concerning the public and local government institutions. 
years will be accelerating due to the expected acceleration of spending EU funds, which will cause the increase in public investments. It is assumed that in 2018, the increase in GDP will be 3.8\% and, in next years, it will be at the level of 3.9\%. The basic growth factor is private national demand. Gross fixed capital formation is expected to rise from $6 \%$ to $6.8 \%$, which should lead to an increase in GDP and economic growth. It is also expected that the consumption price index will increase from $1 \%$ to $2.5 \%$. A significant decline in the unemployment rate will also occur, resulting mainly from demographic conditions. Furthermore, the measure of inequality of incomes (Gini coefficient) shows that dispersion of incomes will be reducing, reaching $27 \%$ by 2030 . In conclusion, the data presented in Table 1 concerning the current status and prognoses for 2020 confirm a good status of the Polish economy in this period.

However, despite such a good economic situation, maintaining current growth requires the increase in innovativeness and transitions from the traditional model based on carbon and steel industry into modern solution and digital economy. Other very important challenges are problems of air pollution, demographics and reduction of the retirement age, which, with longer perspective, can be detrimental to labour market stability.

Therefore, the main strategic goal is to strengthen activities for the achievement of the goals of sustainable development.

\subsection{Priority Areas of Sustainable Development of Cities, Urbanization, National Urban Policy}

Analysis of the problem of quality of life (Forum..,2014, 2017) reveals the complexity and variety of priority areas of sustainable urban development. In autumn 2014, the National Urban Policy (Ministerstwo..,2014) was adopted as a document aimed to integrate the approach to the development of cities of various size in Poland. It highlights 10 thematic areas, presented in Fig. 1.

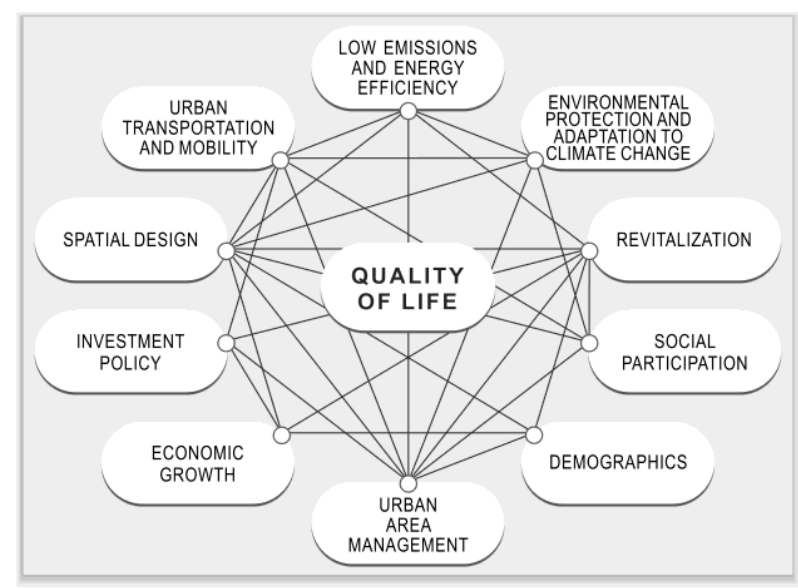

Figure 1. Basic thematic areas for priority areas of sustainable urban development

Source: based on KPM, Forum Odpowiedzialnego Biznesu (2014, 2017).

The realization of each of the presented thematic areas is aimed to ensure higher quality 
of life in cities and saving time connected with functioning in cities. The examples of sustainable cities, districts, and office and commercial building include (Forum..,2014): Copenhagen (Denmark), considered by the EU as a model city; Vancouver (Canada, 2013) the greenest city all over the world; Wałbrzych (Poland, 2014) - the City of Opportunities - City of Sustainable Development; Siewierz near Katowice, Poland garden city; district in Nowe Żerniki in Wrocław, Poland, as a design of a polycentric city; green office building Ecocentrum Warszawa; or Saho Factory Warszawa-Praga space for creativity and culture.

With sustainable development of cities in Poland due to intensifying urbanization processes, a "city centre crisis" was observed i.e. intensive migration of people from central and suburban areas into the areas which are less populated. This leads to extending the size of cities and creation of large urbanized areas. In 2018, the degree of urbanization in Poland represented by the urbanization index ${ }^{4}$ was $60.1 \% 0^{5}$ (The World..,2017). Positive and negative effects of urbanization are presented in Table 2.The data clearly indicate the dominance of positive effect of urbanization for Poland.

Table 2. Positive and negative effects of urbanization

\begin{tabular}{|c|c|c|}
\hline $\begin{array}{l}\text { Aspects of } \\
\text { urbanization }\end{array}$ & Positive effects of urbanizations & Negative effects of urbanizations \\
\hline economic & $\begin{array}{l}\text { Large market, increased work efficiency, } \\
\text { reduced unemployment, extension of } \\
\text { technological infrastructure }\end{array}$ & $\begin{array}{l}\text { increase in prices of housing, } \\
\text { insufficient land for buildings, } \\
\text { traffic jams, overloaded urban } \\
\text { transportation } \\
\text { Problems with water, necessity to } \\
\text { extend treatment plants }\end{array}$ \\
\hline $\begin{array}{l}\text { Socio- } \\
\text { economic }\end{array}$ & $\begin{array}{l}\text { Easiness to find employment, access to } \\
\text { education and public administration, cultural } \\
\text { institutions, easiness to be educated, longer } \\
\text { time for rest }\end{array}$ & $\begin{array}{l}\text { Increased crime rate, social tensions, } \\
\text { reduced sense of safety }\end{array}$ \\
\hline Social & $\begin{array}{l}\text { Higher salaries, elevated quality of life, good } \\
\text { access to social assistance }\end{array}$ & $\begin{array}{l}\text { Low number of flats, increase in the } \\
\text { number of the homeless, } \\
\text { appearance of slums, poor sanitary } \\
\text { conditions }\end{array}$ \\
\hline Health & $\begin{array}{l}\text { Better contact with health care and life- } \\
\text { saving services }\end{array}$ & $\begin{array}{l}\text { Increase in the number of people } \\
\text { with depression, pollution-related } \\
\text { diseases, increased suicide rates }\end{array}$ \\
\hline Ecological & Creation of urban parks & $\begin{array}{l}\text { Increased water and soil pollution, } \\
\text { problem with } \\
\text { waste and utilization, increased } \\
\text { noise intensity }\end{array}$ \\
\hline
\end{tabular}

Source: based on Buro Happold (2014), Global Compact (2016), the Ministry of Infrastructure (2014)

${ }^{4}$ The urbanization index [\%] is the percentage rate of people living in cities compared to total population in a region.

5 according to the author's calculations and based on the World Bank/Rynek Pierwotny.pl, for 28 European countries, mean urbanization index was $73.4 \%$ (max. in Belgium, with $97.9 \%$ and min. in Slovenia, with $49.7 \%)$. 


\section{Attempts to Determine Relations between the Economic Value of the Construction Sector and Consumption of Environmental Resources}

With the level of global sustainable development, the method of its evaluation remains to be a substantial challenge. According to Cebrat (2014) who determined its degree using a dedicated coefficient, one should use the correlations between the economic value and consumption of resources and, assuming that money represents the substitute of specific goods or services, also the used environmental resources. Using this assumption, it was adopted that the values of costs (expressed in cash) incurred by investors balance the realization of investments and consumption of environmental resources. Consequently, the value of consumed environmental resources can be measured by the value of the part of expenditures (costs) incurred in the process of sustainable building.

Using the statistical data, the value of primary energy ${ }^{6}$ consumed per person can be divided by GDP per capita in the same period in order to obtain primary energy needed for generation of 1 PLN of GDP. Next, knowing the mean price of a flat in PLN $/ \mathrm{m}^{2}$, one can compute mean embodied energy in buildings: energy as a replacement of money invested in the building, which balances the value of $1 \mathrm{~m}^{2}$ of a flat for its mean price.

Assuming $E_{0}$ as consumption of primary energy per person in $2016=116$ GJ per capita 7 , and

GDP in dollars (international) per capita as 29,521 \$ per capita ${ }^{8}$, the balancing energy $\mathrm{E}_{\mathrm{r}}$ for the cost of generation of 1 PLN of GDP in 2016 is:

$E_{r}=\frac{E_{0}}{P K B}=\frac{116 \mathrm{GJ} \text { per capita }}{29512 \$ \text { per capita }}=\frac{32222 \mathrm{kWh} \text { per capita }}{52547 \mathrm{zł} \mathrm{per} \mathrm{capita}}=0.61 \frac{\mathrm{kWh}}{z t}$

This means primary energy needed for generation of 1 PLN of GDP in 2016.

In 2016, mean price of a flat was $\mathrm{c}=6205 \mathrm{PLN} / \mathrm{m}^{2}$ (Raport.,2017). Therefore, if the value of primary energy needed for generation of 1 PLN is multiplied by mean price of flat, the value of energy that balances $1 \mathrm{~m}^{2}$ of flat, i.e. the embodied energy in buildings $E_{\mathrm{w}}$ in October 2016, is obtained.

$E_{w}=E_{r} \bullet c=\frac{0,61 \mathrm{kWh}}{z t} \bullet \frac{6205 z t}{\mathrm{~m}^{2}}=3785 \frac{\mathrm{kWh}}{\mathrm{m}^{2}}$

Analysis of the data concerning mean European embodied energy in buildings according to (Hegger et al. (2008) and Hammond et al. (2008) usually reaches the value of ca.

$\bar{E}_{w}=5300 \frac{M J}{\mathrm{~m}^{2}}=1500 \frac{\mathrm{kWh}}{\mathrm{m}^{2}}$

It can be seen that $\mathrm{E}_{\mathrm{w}}$ is greater than mean European embodied energy in buildings $\bar{E}_{w}$

6 The concept of primary energy concerns the energy contained in sources, including fuels and carriers, necessary for covering the demand for final energy

7 Sum of transformation input and direct consumption. Source: GUS (2006-2016), Gospodarka

Paliwowo- Energetyczna w latach 2006-2016, cz. I. Wskaźniki Energo-Ekonomiczne, s. 52

8 Source: International Monetary Fund (2018), World Economic Outlook Database; (1\$=1.78 PLN) 
$\mathbf{E}_{\mathbf{w}}=3785 \frac{k W h}{m^{2}}>\bar{E}_{w}=1500 \frac{k W h}{m^{2}}$

Therefore, embodied energy in buildings $\mathbf{E}_{\mathbf{w}}$ can initially represent the index that provides information not only about the investment but also about balancing of the construction sector or the economy.

Using the relationships (2) for the embodied energy in buildings, prices of flat and energy balancing generation of 1 PLN of GDP can be determined (in the 1st approximation and for conditions of Polish prices in PLN) by mean European embodied energy in buildings $\bar{E}_{r}$ for value $\bar{E}_{w}$ and mean price of flats.

$\bar{E}_{w}=\bar{E}_{r} \bullet c \Rightarrow \bar{E}_{r}=\frac{\bar{E}_{w}}{c}=0,24 \frac{k W h}{z t}$

The result (for these assumptions) provides information that the energy that balances the cost of generation of 1 PLN at European means for 2016 (i.e. primary energy needed for generation of 1 PLN of the European budget) is $0.24 \mathrm{kWh}$. Obviously, the costs in the European countries differ substantially from those observed in Poland. Consequently the first approximation is assumed with substantial care.

The difference between the values of energy for Poland $E_{w}=0,61 \frac{k W h}{z t}$ and for the EU $\bar{E}_{w}=0,24 \frac{k W h}{z t}$ is surprising. The differences can be found in high uncertainty of construction processes in Poland, poor quality of construction materials, technologies and processes which result from particularly low innovativeness in the construction sector and high difference between costs of construction and use.

Furthermore, $\quad \mathbf{E}_{\mathbf{w}}=3785 \frac{\mathrm{kWh}}{\mathrm{m}^{2}}>\bar{E}_{w b}=1500 \frac{\mathrm{kWh}}{\mathrm{m}^{2}}$. This relationship can be connected with the fact that mean embodied energy is a total of energy needed for obtaining raw materials, transport per building site, processing, assembly etc. (GUS, 2012). However, embodied energy in buildings (expressed in cash) is composed not only of physical elements but also the economic value such as consumption of resources, income of subcontractors, suppliers etc. High difference between embodied energy in buildings and mean European embodied energy is likely to partially reflect consumption of natural resources. If this assumption is made, the situation is assessed negatively from the standpoint of sustainable development.

As shown by the analysis, the index that characterizes embodied energy in cash can represent a good approximation of the sustainability index. An open question is a correlation between the level of the effect of investments on the environment and costs of its generation. It can be concluded that the lower the value of embodied energy in cash the less money spent on construction and lower consumption of environmental resources.

\section{Conclusion}

The study assessed the sustainable development in the construction sector in the 
context of urban development and indicated the necessity of the ecological approach in the construction sector for which, as a leading sector, the priority is sustainable development.

Sustainable building technologies were presented, indicating measurable savings resulting from their application. Business was emphasized as a major inspirer of the partnership for sustainable cities and urban areas. The necessity of transformation of the economy into modern solutions and digital economy was indicated. Furthermore, positive and negative effects of urbanization were discussed and the attempts were made to establish the correlations between economic value of the construction sector and consumption of environmental resources. The analysis and the presented assessment of sustainable development of cities in Poland shows that the thesis adopted in the study was confirmed and the study aim was achieved.

\section{References}

Brelsford, Ch., Lobo, J. et al. (2017). Heterogeneity and scale of sustainable development in cities. Proceedings of the National Academy of Sciences the United State of America, vol.114, Issue 34,

Bunikowska J. (2010). Przyszłość europejskiego sektora budowlanego.Zrównoważone budownictwo. Biuletyn Euro Info

Buro Happold (2014). Analiza rynku zrónnoważonego budownictwa w Polsce. Badanie percecji rynku. Construction Marketing Group, World Green Building Council, p. 10

Cebrat K. (2014). Nie-zrównoważony rynek mieszkaniowy w Polsce. Analiza danych statystycznych i wskaźnik energii wbudowanej w pieniądz jako nowe narzędzie oceny zrównoważenia. Architectus, $\mathrm{Nr} 2(38)$

CSRinfo (2017). Annual CSR Outlook 2017. Retrieved 10.10.2017 from http://www.csrinfo.org/wpcontent/uploads/2017/03/Annual-CSR-Outlook_2017.pdf

Forum Odpowiedzialnego Biznesu (2014), Biænes na rzecz, zrównoważonych miast.Retrieved 02.09. 2015 from http://odpowiedzialnybiznes.pl/wp-content/uploads/2014/07/Analiza-tematyczna-Biznes-narzecz-zrównoważonych-miast.pdf

Forum Odpowiedzialnego Biznesu (2017), Raport. Odpowiedrialny Biznes w Polsce. Dobre Praktyki. Retrieved 10.10.2017 from http://odpowiedzialnybiznes.pl/wp-content/uploads/2018/04/Raport 2017.pdf

Global Compact Network Poland, (20161) Zrównoważone miasta. Życie w żdrowej atmosferže, Retrieved 15.11.2016 fromhttp://ungc.org.pl/wp-content/uploads/2016/10/GC_ZM_www_060117

Global Compact Network Poland, (20162), Cele zrównoważonego rozwoju ONZ, Retrieved 15.11. 2016 from http://www.csrinfo.org/wp-content/uploads/2016/10/Kamil-Wyszkowski-UN-GlobalCompact-w-Polsce-SDGs-2015-30-realizacja-globalnego-planu-rozwoju_Warszawa-25.10.pdf

Global Compact Network Poland, (2016-2017) Global Goals for Sustainable Development (Cele Zrównoważonego Rozwoju ONZ), (2016-2017). Retrieved 15.04.2017 from http://www.csrinfo. org/wpcontent/uploads/2016/10/Kamil-Wyszkowski-UN-Global-Compact-w-Polsce-SDGs- 2015-30realizacja-globalnego-planu-rozwoju_Warszawa-25.10.pdf

Gorzen-Mitka, I., Skibinski, A., Lemanska-Majdzik, A. (2016). Rating of European Housing Markets by MultiObjective Evaluation Method. Proceedings of the 3rd International Conference on European Integration 2016 (ICEI 2016), pp. 263-272, 2016

GUS, (2012). Gospodarka paliwowo-energetyczna w latach 2010-2011.Warszawa

Hegger M., Fuchs M., Stark T., Zeumer M., (2008). Energy manual. Sustainable Architecture, Birkhauser, BaselBerlin

Hammond G.P.,Jones C.I.,(2008).Embodied energy and carbon in construction materials, Proceeding of the Institution of Civil Engineers-Energy, No.161(2), 93

Ministerstwo Infrastruktury i Rozwoju (2014). Krajowa Polityka Miejska.Retrieved 10.10 .2015 from https://www.mir.gov.pl/media/4525/Krajowa_Polityka_Miejska_wersja_I_27032014.pdf 
OECD (2017). Agenda na rzecz zrównoważonego rozpoju 2030: W Kierunku Lepszego Wdrożenia w Polsce.Seria "Lepsza Polityka Państwa". https://www.oecd.org/poland/Better-Policy- Series Poland-Nov2017-PL.pdf

Ostrowiecki D. 2015, Sektor prywatny w świetle wizji zrównoważonego rozwoju dla polskiego biznesu 2050, Wydawnictwo Uniwersytet w Bialymstoku, s. 259-271

Raport Bankier.pl. (2017). Ceny ofertowe mieszkań - grudzień 2017 r. Retrived 01.03.2018 from https://www.bankier,pl /wiadomosc/Ceny-ofertowe-mieszkan-grudzien-2017-Raport-Bankier-pl7562812.html

Rodriguez, R.S., Urge-Vorsatz, D., Barau, A.S. (2018). Sustainable_Development_Goals and climate change adaptation in cities. Nature Climate Change. Vol. 8, Issue 3, pp. 181- 183

SeP, Innowacje, zrónnoważony rozwój $i$ demografia to tray stabe punkty polskiej gospodarki.( 2018). Retrieved 02.03.2018 from https://www.bankier.pl/wiadomosc/S-P-innowacje-zrownowazony- rozwoj-idemografia-to- trzy-słabe-punkty-polskiej-gospodarki-7575943.html

Sipa, M., The Factors Determining the Creativity of the Human Capital in the Conditions of Sustainable Development. European Journal of Sustainable Development. Vol. 7, Issue2, pp. 1-13, 2018

Sitek, M., (2016). Management of the Creation Process of Residential Buildings. Polish Journal of Management Studies, Vol. 14, Issue 2, pp. 203-213

The Conference Board (2017). Global Consumer Confidence, Retrieved 05.10.2017 from http://www.nielsen.com/content/dam/nielsenglobal/de/docs/2017_Q4_GlobCIReport.pdf.

The World Factbook (2017). Retrieved 05,10,2017 from https://www.cia.gov/library/publications/ theworld-factboo/fields/2212.html 